\section{F.A. Ahmed}

\section{B.A. Babiker 1}

T.M. Mohamed ${ }^{1}$

T.E. Ali 1

\section{The effect of genetic upgrading of Kenana (Sudan zebu cattle) with European Friesian on calf performance, milk yield and milk composition}

AHMED (F.A.), BABIKER (B.A.), MOHAMED (T.M.), ALI (T.E.). Amélioration génétique par croisement entre la race Kenana (bétail zébu du Soudan) et la race Frisonne européenne : effet sur la performance des veaux, la production laitière et la composition du lait. Revue Élev. Méd. vét. Pays trop., 1992, 45 (3-4) : 329-333

Deux expériences ont été réalisées afin de déterminer l'effet du croisement de la race indigène Kenana avec 50 ou 75 p. 100 de race Frisonne sur la performance des veaux, la production et la composi. tion du lait. Dans l'expérience I, la consommation de matic̀re sc̀che, le gain de poids vif et l'indice de consommation ont été étudiés avant et après le sevrage. Concernant la consommation de matière sèche, aucune différence significative n'a pu être mise en évidence entre les deux groupes de génotypes. En revanche, durant la période de présevrage, le poids vif est statistiquement plus élevé chez les croisés Frison à 75 p. 100 que chez les croisés Frison à 50 p. 100, tandis que durant la période de post-sevrage, il est significativement plus élevé chez les croisés à 50 p. 100 que chez ceux à 75 p. 100 . En ce qui concerne l'indice de consommation, les croisés Frison à 50 p. 100 présentent des valeurs supérieures à celles des croisés à $75 \mathrm{p} .100$ durant la période de pré-sevrage, tandis qu'il est plus élevé chez les croisés à 75 p. 100 que chez ceux à 50 p. 100 durant la période de post-sevrage. Dans l'expérience II, les vaches Kenana croisées avec 50 p. 100 de Frison ont produit significativement plus de lait que les croisés à 75 p. 100, mais avec une teneur moins élevée en matières grasses et en protéines. Les meilleures performances ont généralement été enregistrées chez le génotype à $50 \mathrm{p} .100$ Frison. Il apparaît ainsi que les plans de croisements futurs devront faire l'objet d'une gestion attentive. Mots clés : Bovin Frison x Kenana - Croisement - Veau - Sevrage Croissance - Production laitière - Lait - Teneur en lipides - Teneur en protéines - Soudan.

\section{INTRODUCTION}

It is now a widely accepted practice in many countries in the tropics to upgrade the indigenous dairy cattle by crossing with exotic temperate breeds to improve the productivity of the former. In these countries much information has been gathered and published on the performance of the crossbreds regarding parameters like milk yield, lactation length, age at first calving and calving interval $(3,10$, $14,19,31)$. Amongst the other important traits in dairy cattle are viability and milk composition. In a recent review on crossbreeding Bos indicus and Bos taurus for milk production in the tropics, CUNNINGHAM and SYRSTAD (9) indicated that records on such parameters have rarely been reported.

1. University of Gezira, Faculty of Agricultural Sciences, Department of Animal Science, POB 20, Wad Medani, Soudan.

Reçu le 28.9.1989, accepté le 13.4.1993.
The Kenana cattie is a subtype of the Northern Sudan Shorthorn Zebu (Bos indicus) introduced many centuries ago with migrants from Asia $(6,17)$. They are generally considered to have resulted from interbreeding with Sanga cattle and Shorthorn Zebu (25). The average milk yield of large herds has been reported to be $1500 \mathrm{~kg} / \mathrm{lac}-$ tation (8). Mature cows may be $130 \mathrm{~cm}$ high at shoulder and weigh up to $450 \mathrm{~kg}$. They are light blue grey with graduation from nearly white to steel grey and they are found East of the confluence of the Blue and White Niles as far as the Ethiopian border (26). The crosses described in this work result from artificially inseminated Kenana cows with imported Friesian semen from Great Britain. The aim of the present work was to study the calf performance, milk yield and composition of 50 and $75 \%$ Friesian upgraded Kenana (Sudan indigenous Zebu) cattle. The investigation was carried out in the Central Region of the Sudan where a developing dairy industry is being based on crossbred cattle.

\section{MATERIALS AND METHODS}

Two experiments were carried out at the University of Gezira Farm (latitude $14^{\circ} 30^{\prime}$, longitude $33^{\circ} 39^{\prime}$ ) during the years 1985 to 1987. Experiment I was carried out during the period of January 1985 to March 1986. The average temperature and humidity during this period was $31^{\circ} \mathrm{C}$ and $42.5 \%$, respectively. Experiment II was carried out during the period January to March 1987, the average temperature and relative humidity during which was $26.9^{\circ} \mathrm{C}$ and $32.3 \%$, respectively. In experiment $\mathrm{I}$, Friesian $x$ Kenana crossbred calves were used to study the effect of genotype on feed intake, liveweight gain and feed conversion efficiency by calves up to the age of 26 weeks. In experiment II, milk yield and composition (fat and protein) were studied in Friesian $\mathrm{x}$ Kenana crossbred cows.

\section{Experiment I}

\section{Animals and management}

Sixty four Friesian $x$ Kenana crossbred calves were used of which 32 were $50 \%$ Friesian, $50 \%$ Kenana and 32 were $75 \%$ Friesian, $25 \%$ Kenana crosses. 
After delivery, the calves were weighed and transferred to individual feeding pens where they received colostrum by nipple pail feeding system within, at most, one hour. The quantity of colostrum offered in the first 4-6 h was about $10 \%$ of the calves' birthweight. Colostrum feeding continued for $48 \mathrm{~h}$. The calves were then bucket-fed from their mothers' milk for the following five days after which they received farm milk till weaning. The daily amount of milk was given in two equal portions, one in the morning and one in the evening. The calves were weaned at ages of 6 , 8,10 and 12 weeks. Starter concentrate rations composed of cottonseed meal, groundnut meal, wheat bran, molasses, oyster shell and common salt providing $175 \mathrm{~g} / \mathrm{kg}$ DM of crude protein and $11.4 \mathrm{MJ} / \mathrm{kg}$ DM metabolizable energy (ME) were introduced to the calves at the end of their first week of age and continued till weaning. During the post-weaning period, the calves were reared collectively in group pens. Supplement rations composed of the same dietary ingredients as those used for the starter rations were used. However, the diet provided a crude protein content of $155 \mathrm{~g} / \mathrm{kg} \mathrm{DM}$ and 11.3 MJ/kg DM (ME). Table I shows the ingredients and their chemical composition (starter and supplement feeds). Forage sorghum (Sorghum vulgarae var. Abu70) was offered to the calves. The forage was daily cut in the preblooming stage and offered fresh and green. The daily feed intake and fortnightly liveweight were recorded. This period continued till the age of 26 weeks. All calves were vaccinated against rinderpest, blackquarter, haemorrhagic septicaemia and anthrax. They were sprayed weekly with an acaricide against ticks.

\section{Experiment II}

\section{Animals and management}

Fourteen milking cows were used in this experiment. Ten cows were $50 \%$ Friesian, $50 \%$ Kenana while the other

TABLE I Ingredients and chemical composition of the starter and supplement feeds used for calves in Experiment I.

\begin{tabular}{|l|c|c|}
\hline Ingrédient (g/kg) & Starter diet & Supplement diet \\
\hline Cottonseed cake & 350 & - \\
Groundnut cake & - & 120 \\
Wheat bran & 550 & 720 \\
Molasses & 090 & 150 \\
Oyster shell & 005 & 005 \\
Common salt (NaCl) & 005 & 005 \\
Chemical Composition & & \\
Crudg DM) & 175 & 155 \\
Ether extract & 038 & 030 \\
Crude fibre & 122 & 108 \\
Nitrogen Frce Extracts & 605 & 635 \\
Ash & 060 & 072 \\
Energy (MJ/kg DM) & 11.4 & 11.3 \\
\hline
\end{tabular}

four were $75 \%$ Friesian, $25 \%$ Kenana. All the cows were in their third lactation and were hand-milked twice daily at 03:00 and 13:00 h. Milking was initiated by offering the concentrate diet and was carried out at the milking parlour. The animals were kept in a spacious shaded pen. The cows were let to graze from 09:00 to 12:00 h. Grazing was on swards of Berseem (Trifolium alexandrinum L.) and Clitoria (Clitoria ternatae). In addition to grazing, a concentrate ration composed of wheatbran $(530 \mathrm{~g} / \mathrm{kg})$; groundnut meal $(350 \mathrm{~g} / \mathrm{kg})$, molasses $(100 \mathrm{~g} / \mathrm{kg})$, mineral and vitamin supplements $(20 \mathrm{~g} / \mathrm{kg})$, providing $250 \mathrm{~g} / \mathrm{kg}$ DM crude protein was offered. The quantity of concentrate per cow was calculated according to its milk production. Individual milk yields were recorded. The experimental period lasted 75 days.

\section{Chemical analysis}

The chemical composition of the feeds was determined by proximate analysis according to the standard methods adopted by the A.O.A.C. (4).

An aliquot sample of milk was taken from each cow in the morning every three days, during the whole period of the experiment. The milk samples were analysed for fat and protein $(\mathrm{N} \times 6.38)$ by the standard Gerber's and formol (formaldehyde reaction) methods, respectively.

\section{Statistical analysis}

The data in experiment I were analysed by analysis of variance using Duncan's Multiple Range Test according to STEEL and TORRIE (30). T-Test was used for the analysis of the data in experiment II according to SNEDECOR and COCHRAN (29).

\section{RESULTS}

The effect of genotype (75 and $50 \%$ Friesian Zebu crosses) on feed consumption and performance of the crossbred calves during the whole experimental period is shown in table II. During the preweaning period (0-12 weeks) the dry matter intake which included that of milk, supplement and forage, although it was slightly higher for the $75 \%$ Friesian group showed no significant difference between the two genotypes. However, the $75 \%$ Friesian genotype showed a significantly $(P<0.001)$ higher liveweight gain than the $50 \%$ Friesian group. On the other hand, the feed conversion ratio was significantly $(P<0.01)$ higher for $50 \%$ than for $75 \%$ Friesian crosses. During the postweaning period (12-26 weeks), there was no significant difference in dry matter intake between both genotypes. The $50 \%$ Friesian group of calves showed a significantly $(P<0.001)$ higher liveweight gain than the $75 \%$ Friesian group. Feed conversion ratio was signifi- 
cantly $(P<0.01)$ higher and favourably $(P<0.001)$ lower for $50 \%$ than for $75 \%$ Friesian crosses, during the preweaning and postweaning periods respectively.

The mean values of milk yield, fat and protein for both groups of genotypes are shown in table III. The $50 \%$ Friesian group produced a significantly $(P<0.001)$ higher milk yield than the $75 \%$ Friesian group. On the other hand, the fat and protein content of their milk was significantly $(P<0.001)$ lower than that of the $75 \%$ Friesian group.

\section{DISCUSSION}

The results of this study show a significant effect of the genotype on the growth of calves over both the preweaning and postweaning period. BHAT et al (5) reported that in Friesian Zebu crosses the genotype had a significant effect on body weight at all ages. In the study reported here, $75 \%$ Friesian calves showed a significantly higher growth in the preweaning period than the $50 \%$ crosses. PLANAS PEREZ (23) reported that growth rate was higher up to 12 weeks for the $75 \%$ Friesian than for others. When considering the growth of the calves over the whole period of study (26 weeks) $50 \%$ Friesian calves had a significantly higher growth than $75 \%$ Friesian calves. Perhaps with time the $75 \%$ Friesian became less able to withstand climatic conditions and

TABLE II The effect of genotype on the average drymatter intake, average liveweight gain and feed conversion ratio of Friesian $x$ Kenana crossbred calves during preweaning (0-12 weeks) and postweaning (12-26 weeks) period.

\begin{tabular}{|c|c|c|c|}
\hline \multirow{2}{*}{} & \multicolumn{2}{|c|}{ Genotype } & \multirow{2}{*}{$\begin{array}{c}\text { S.E. } \\
\text { and level } \\
\text { of }\end{array}$} \\
\cline { 2 - 3 } & $\begin{array}{c}50 \% \\
\text { Friesian } \\
50 \% \\
\text { Kenana }\end{array}$ & $\begin{array}{c}75 \% \\
\text { Friesian } \\
25 \% \\
\text { Kenana }\end{array}$ & $\begin{array}{c}\text { significance } \\
\text { Kenan }\end{array}$ \\
\hline $\begin{array}{c}\text { Drymatter intake } \\
\text { (kg/head/day) }\end{array}$ & 0.84 & 0.86 & $0.037 \mathrm{NS}$ \\
$\begin{array}{c}\text { Preweaning } \\
\text { Postweaning } \\
\text { (kg/100 kg LW/day) }\end{array}$ & 1.95 & 1.99 & $0.052 \mathrm{NS}$ \\
$\begin{array}{c}\text { Preweaning } \\
\text { Postweaning }\end{array}$ & 1.56 & 1.44 & $0.127 \mathrm{NS}$ \\
Liveweight gain & 1.90 & 1.90 & $0.074 \mathrm{NS}$ \\
(kg/head/day) & & & \\
Prewaening & 0.28 & 0.31 & $0.072^{\star \star \star}$ \\
$\begin{array}{c}\text { Postweaning } \\
\text { Feed conversion ratio }\end{array}$ & 0.50 & 0.46 & $0.036^{\star \star \star}$ \\
\hline Preweaning & 2.94 & 2.70 & $0.001^{\star \star}$ \\
Postweaning & 3.89 & 4.30 & $0.001^{\star \star}$ \\
\hline
\end{tabular}

less able to use the available feed as efficiently as the $50 \%$ Friesian. Long ago, HOWE (11) reported that the slow growth rate of purebred Holstein calves in the tropics was due to the inability of such breeds to withstand the climatic conditions and the restriction of feed due to the inability of such animals to metabolize properly, at high temperatures, enough feed for normal existence. Other workers $(22,32)$ stated that the superiority of halfbred over $3 / 4$ foreign blood animals was due to their high hybrid vigour. The results of this study is in agreement with the findings of RATHORE (24) who reported that $50 \%$ Friesian, $50 \%$ Zebu had faster growth than $75 \%$ Friesian, $25 \%$ Zebu. Also our results confirm the findings of ALRAWI and SAID (2) who found that daily gain decreases as the percentage of the Friesian blood increases. In this study the feed conversion efficiency was found to be significantly better for $50 \%$ than for $75 \%$ Friesian crosses in the postweaning period (12-26 weeks) and over the total period.

The results of this study show that $50 \%$ Friesian crosses cows produced a significantly higher milk yield than $75 \%$ Friesian crosses. This agrees with what had been reported by NARAYANASWAMY (21) when he compared Friesian-Sahival crosses (1/2, 5/8 and 3/4 Friesian) and found that the superiority of the total milk yield was in the order of half Friesian > 5/8 Friesian > 3/4 Friesian. ALBA and KENNEDY (1) showed that the F1 (Criollo $x$ Jersey) crosses were superior to the Criollo breed and $1 / 4$ Jersey. In India SHARMA et al (28) found that with 1/8, 1/4, 1/2. $5 / 8$ and $3 / 4$ Friesian blood, the average milk yield was higher for $1 / 2$ Friesian than for the other groups. KALE et al (12) in their studies with different grades of HolsteinFriesian by Gir and Sahiwal crosses concluded that there was no advantage in increasing the Holstein-Friesian inheritance beyond $50 \%$. The same conclusion was reached earlier by NAIR (20) when crossing Zebu cattle with Brown Swiss.

TABLE III The effect of genotype on the average milk yield, milk fat and milk protein of Friesian $x$ Kenana crossbred cows (means + S.D.).

\begin{tabular}{|c|c|c|c|}
\hline & \multicolumn{2}{|c|}{ Genotype } & \multirow{2}{*}{$\begin{array}{c}\text { T-test } \\
\text { Level } \\
\text { of } \\
\text { significance }\end{array}$} \\
\hline & $\begin{array}{c}50 \% \\
\text { Friesian } \\
50 \% \\
\text { Kenana }\end{array}$ & $\begin{array}{c}75 \% \\
\text { Friesian } \\
25 \% \\
\text { Kenana }\end{array}$ & \\
\hline $\begin{array}{l}\text { Milk yield } \\
\text { (V/cow/day) }\end{array}$ & $11.01+0.399$ & $9.20+0.726$ & $\star \star \star *$ \\
\hline $\begin{array}{l}\text { Milk fat } \\
(\mathrm{g} / \mathrm{kg})\end{array}$ & $42.0+2.14$ & $45.9+3.81$ & $\star \star \star$ \\
\hline $\begin{array}{l}\text { Milk protein } \\
(\mathrm{g} / \mathrm{kg})\end{array}$ & $31.0+1.60$ & $32.6+2.06$ & $* * *$ \\
\hline
\end{tabular}

S.D. : Standard deviation.

***: Significant at $P<0.001$. 
In Kenya, MEYN and WILKINS (18), analysing data on a farm of Jersey and Jersey $x$ Sahiwal showed that the crosses produced $16 \%$ more milk than the purebreds. With Ayrshire and Sahiwal $x$ Ayrshire crosses KIMENYE and RUSSEL (13) reported higher milk yield for the 50 and $75 \%$ Ayrshire than for the high-grade Ayrshire and they concluded that a "fair portion of Bos indicus genes is desirable in this environment". In the coastal region of Tanzania, MAHADEVAN and HUTCHINSON (16) comparing a range of crossbreds of Bos indicus and Bos taurus showed that the $50 \%$ Bos taurus cross had slightly higher milk yield than the 25 and $75 \%$ crosses. The records collected from Northern Nigeria involving White Fulani and Friesian were analysed by BUVANENDRAN et al (7) and they showed that the milk yield in all lactations of the $50 \%$ crosses of the two breeds exceeded the $75 \%$ Friesian crosses by $100 \%$ (287 kg vs $143 \mathrm{~kg}$ ). On the other hand, the milk yield in the first and second lactation of Ndama and Jersey crosses in the Ivory Coast was higher for $75 \%$ than for $50 \%$ crosses Jersey crosses (15).

Although the $75 \%$ cross benefit regarding milk production levels was clearly visible after the second lactation, the lack of resistance of these crosses towards the wet tropical environment made no progress beyond the $50 \%$ cross with the Ndama $x$ Jersey cattle and numerous health problems occurred from the third lactation (15).

AHMED (F.A.), BABIKER (B.A.), MOHAMED (T.M.), ALI (T.E.). The effect of genetic upgrading of Kenana (Sudan Zebu cattle) with European Friesian on calf performance, milk yield and milk composition. Revue Élev. Méd. vét. Pays trop., 1992, 45 (3-4) : 329-333

Two experiments were undertaken with Friesian $x$ Kenana crosses to study the effect of 50 and $75 \%$ upgraded indigenous cattle on calf performance, milk yield and milk composition. In experiment $I$, the dry matter intake, liveweight gain and food conversion ratio of preweaned and postweaned calves were studied. There was no significant difference in dry matter intake between both genotype groups. I iveweight was significantly higher for $75 \%$ than for $50 \%$ Friesian crosses during the preweaning period while it was significantly higher for $50 \%$ than for $\mathbf{7 5} \%$ crosses during the postweaning period. Food conversion ratio was higher for $50 \%$ than for $75 \%$ crosses during the preweaning period while it was higher for $75 \%$ than for $50 \%$ crosses during the postweaning period. In experiment II, $50 \%$ crossbreed cows produced significantly more milk than $75 \%$ crosses but their milk composition was lower in fat and protein concentration. Generally, the results indicate a better performance of the $50 \%$ upgraded genotype. Future upgrading plans should be carefully monitored. Key words : Friesian x Kenana cattle - Crossbreeding - Calf Weaning - Growth - Milk yield - Milk - Fat content - Protein content The Sudan.
Both milk fat and milk protein were significantly higher for $75 \%$ than for $50 \%$ Friesian cows. SHARMA et al (27) in their studies with Brown Swiss and Zebu crosses report that the yield of fat significantly decreased in the F1 compared to the F2 generations.

\section{CONCLUSION}

It was shown that over the 26-week study period, the growth of $50 \%$ Friesian calves was significantly faster than that of $75 \%$ Friesian calves. It was also shown that $50 \%$ Friesian cows exhibited a significantly higher milk yield but a lower milk protein and milk fat content than the $75 \%$ Friesian cows. Hence, under the conditions of this study the $50 \%$ Friesian crosses seemed to perform better than the $75 \%$ crosses. These results indicate that future upgrading plans should be carefully and cautiously monitored.

\section{ACKNOWLEDGEMENTS}

We wish to thank Nisheishiba Farm staff and workers for the assistance in the care of the animals.

AHMED (F.A.), BABIKER (B.A.), MOHAMED (T.M.), ALI (T.E.) Efecto del cruce de ganado Kenana (ganado cebú de Sudán) para el mejoramiento genético del desarrollo de los terneros y de la producción y composición de leche. Revue F́lev. Méd. vét. Pays trop., 1992, 45 (3-4) : 329-333

Se llevaron a cabo dos experimentos con cruces de ganado Frisón $x$ Kenana, con el fin de estudiar los efectos de cruces al 50 p. 100 y 75 p. 100 de ganado nativo, sobre el desarrollo de los terneros, la producción y la composición de la leche. En el primer experimento se estudió el consumo de materia seca, la ganancia de peso y la tasa de conversión alimenticia en terneros pre y post destete. No se encontró una diferencia significativa en cuanto a la ingestión de materia seca entre los dos genotipos. El peso vivo fue significativamente más elevado para los cruces al 75 p. 100 durante el pre destete, mientras que en el post destete la ganancia de peso fue significativamente mayor para los cruces al 50 p. 100. La tasa de conversión alimenticia fue significativamente más alta para los cruces al 50 p. 100 durante el pre destete, pero durante el post destete esta tasa fue más elevada para los cruces al 75 p. 100. Durante el segundo cxperimento, las vacas de cruces al 50 p. 100 tuvieron una producción significativamente mayor, pero con un contenido menor de grasa y proteínas. Los resultados generales mostraron un mejor rendimiento del genotipo 50 p. 100. En el futuro, deben observarse cuidadosamente los cruces que se lleven a cabo. Palabras claves : Bovino Frison x Kenana - Cruzamiento Ternero - Destete - Crecimiento - Producción láctea - Leche - Contenido de grasa - Contenido proteico - Súdan. 


\section{ZOOTECHNIE, GENETIQUE ET REPRODUCTION}

\section{REFERENCES}

1. ALBA (J.)(de), KENNEDY (B.W.). Criollo and temperate dairy cattle and their crosses in a humid tropical environment. Rome, FAO, 1984. (FAO Animal Production and Health Paper : 44/1)

2. ALRAWI (A.A.), SAID (S.L.). Some source of variation associated with preweaning growth in purebred and crossbred Friesian. Anim. Breed. Abstr., 1981, $49: 347$.

3. AMBLE (V.N.), JAIN (J.P.). Comparative performance of different grades of crossbred cows on military farms in India. J. Dairy Sci., 1967, $\mathbf{5 0}: 1695-1702$.

4. Association of Official Analytical Chemists (A.O.A.C.). Official Methods of analysis. 12th ed. Washington DC, 1975:

5. BHAT (P.N.), KOUL (S.K.), STANTIAGO (T.C.), GARY (R.C.). Note on body weight of Haryana cattle and their Friesian crosses. Indian J. Anim. Sci., 1982, $52: 35$.

6. BOYNS (B.M.). Sudanese cattle as milk producers. Emp. J. Expl Agric., 1947, 15 : $27-41$.

7. BUVANENDRAN (V.), OLAYIWOLE (M.B.), PIOTROWSKA (K.I.), OYEJOLA (B.A.). A comparison of: milk production trails in Friesian x White Fulani crossbred cattle. Anim. Prod., 1981, 32 : 165-170.

8. CUNNINGHAM (E.P.). Conservation of the Kenana breed in the Sudan. In : Animal genetic resources strategies for improved use and conservation. Rome, FAO, 1983. (FAO Animal Production and Health paper $\mathrm{N}^{\circ}$ 66) Pp. 1-10.

9. CUNNINGHAM (E.P.), SYRSTAD (O.). Crossbreeding Bos indicus and Bos taurus for milk production in the tropics. Rome, FAO, 1987. (FAO Animal Production and Health paper $\mathrm{N}^{\circ}$ 68)

10. FAHMY (S.K.), FAHIM (M.A.), ATTEYA (M.), EL MEHALAWY (M.Y.). Dairy shorthorn and its crusses in Egypl. Agric: Res: Rev., Cairo, 1976, 54 (7) : 79-87.

11. HOWE (J.W.). The effect of varying amounts of Zebu blood on the adaptability of the cattle to conditions in Jamaica. Trop. Agric., Trinidad, 1949, $26: 131$.

12. KALE (A.M.), BHAGAT (S.S.), PATIL (S.S.). Evaluation of different grades of Holstein Friesian x Gir and Sahiwal crosses on the basis of production and reproduction efficiency. Lvstk Advisor, 1984, $9: 5-8$.

13. KMMENYE (D.), RUSSELL (W.S.). Comparison of Ayrshire x Sahiwal cows with high grade Ayrshire in Kenya. E. Afr. Agric. For. $J ., 1975,40: 416-421$.

14. KIWUWA (G.H.), TRAIL (J.C.M.), KURTU (M.Y.), WORKU (G.), ANDERSON (F.), DURKIN (J.). Crossbred dairy cattle productivity in Arsi Region, Ethiopia. ILCA Research Report N¹1. Addis Ababa, 1983.

15. LETENNEUR (L.). Crossbreeding N'Dama and Jersey cattle in Ivory Coast. Wld Anim. Rev., $1978,27: 36-42$.

16. MAHADEVAN (P.), HUTCHINSON (H.C.). The performance of crosses of Bos taurus and Bos indicus cattle for milk production in the coastal region of Tanganyika. Anim. Prod., 1964, 6 : 331-336.

17. MASON (I.), MAULE (C.). The indigenous livestock of eastern and southern Africa. Technical communication $\mathrm{N}^{\circ} 14$. Farnham Royal U.K., Commonwealth Bureau of Animal Breeding and Genetics (CAB), 1960.

18. MEYN (K.), WILKINS (J.V.). Breeding for milk in Kenya with particular performance to Sahiwal Stud. Wld Anim. Rev., 1974, 11 : 24-30.

19. NAGARCENKAR (R.), RAO (M.K.). Performance of Tharparkar-exotic crosses for productive and reproductive traits. Indian $J$. Anim. Sci., 1983, 52 (3) : 129-138.

20. NAIR (P.M.R.). Cattle improvement through crossbreeding. In: XIXth International Dairy Congress, New Delhi, 1974.

21. NARAYANASWAMY (M.). Studies on growth, production and reproduction efficiency in Friesian x Sahiwal crosses. Anim. Breed. Abstr., 1981, $\mathbf{5 0}: 4396$.

22. PAHNISH (O.F.), PORNKS (J.S.), KNAPP (B.W.), RAILY (T.M.). Results from crossbreeding beef $x$ beef and beef $x$ dairy breeds : Calf performance to weaning. J. Anim. Sci., 1969, $28: 291$.

23. PLANAS PEREZ (M.T.). Study on the performance of different Holstein-Zebu crosses in tropical conditions. Anim. Breed. Abstr., $1980,40: 514$.

24. RATHORE (A.). Differences in the growth of Sindi crosses with Jersey, Brown Swiss, Holstein Friesian and Gurnsey cattle. Anim. Breed. Abstr., 1952, $20: 330$.

25. ROUSE (J.). World cattle. II. Cattle of Africa and Asia. Oklahoma City, USA, Oklahoma Univ. Press, 1972.

26. SAEED (A.M.), WARD (P.N.), DURKIN (J.W.), LIGHT (D.), WILSON (R.T.). Results of preliminary analysis of the characterization of Kenana cattle at Um Banein, Sudan. Addis Ababa, ILCA, 1985.

27. SHARMA (K.N.S.), JAIN (D.K.), BHATNAGAR (D.S.), SHARMA (R.C.). Estimation of milk fat solids-non-fat and total solid pronction in Zebu and their Brown Swiss crosses. Anim. Prod., 1983, 36 : 383-387.

28. SHARMA (D.B.), SINGH (C.S.P.), MISHRA (H.R.). Note on the performance of different grades of Friesian $x$ Sahiwal crosses. Asian J. Dairy Res., 1984, $2: 59-62$.

29. SNEDECOR (G.W.), COCHRAN (W.G.). Statistical methods. 6th ed. Ames, Iowa, USA, Iowa State Univ. Press, 1967.

30. STEEL (R.G.O.), TORRIE (J.H.). Principles and procedures of statistics. New York, McGraw Hill Book Co., 1960.

31. TANEJA (V.K.), CHAWLA (D.S.). Heterosis for economic traits in Brown Swiss x Sahiwal crosses. Indian J. Dairy Sci., 1978, 31 (3) : 208-213.

32. TOUCHBERRY (R.W.), BERESKIN (B.). Body growth in purebred and crossbred dairy cattle. J. Dairy Sci., $1965,48: 791$. 